\title{
Sculpture house in Belgium by Jacques Gillet
}

\author{
S. Van de Voorde, R. De Meyer, E. De Kooning, L. Taerwe \\ \& R. Van De Walle \\ Ghent University, Belgium
}

\begin{abstract}
The Belgian architect Jacques Gillet designed the sculpture house in Liège (1967-1968) as a synthesis of structure and form, collaborating on this project with the sculptor Félix Roulin and the engineer René Greisch. This 'livingsculpture' was undertaken by the team as a reaction against the general pressure of that time towards standardisation of forms in architecture, in which an artistic poverty and deficiency needed to be counterbalanced through collaboration with sculptors and painters. The merit of the artistic collaboration is evident when looking at the scheme of the building yard. The materials and techniques used gave the team a creative liberty: steel bars were folded, and placed one by one, to enhance the contingency between nature, space, material and poetry. A metal mesh was affixed to the steel bars and the ultimate form was then secured by projecting a fast setting concrete onto it: direct, immediate and efficient. The exterior is just the mere envelope of the interior; no additional structure whatsoever was necessary. The structure was left bare on the outside, postulating a true unity between form and material.
\end{abstract}

Keywords: architecture, gun concrete, sculpture house, organic, Belgium, Jacques Gillet, Félix Roulin, René Greisch.

\section{Introduction}

Since the end of the Second World War, organic architecture has appeared as a search for beauty that concurs with the notion of ideal construction, as a synthesis of art and sciences. Protagonists of this tendency were, among others, Frederick Kiesler, Mathias Goeritz, Jacques Couëlle, André Bloc and Paul Virilio. Likely the best known example of this architecture, based on organic or sculptural forms is Le Corbusier's Chapel at Ronchamps. The term 'sculptural 
architecture' or 'architectural sculpture' was used for the first time in 1963 by Michel Ragon, in his book 'Où vivrons-nous demain?' [1].

The origins of this movement go back as far as the end of the $19^{\text {th }}$ century, with the work of Louis Sullivan and Frank Lloyd Wright in the USA, and Victor Horta and Antonio Gaudi in Europe. Gaudi achieved a synthesis of shape, structure and form, comparing wire skeletons and plaster models with the laws of nature. The sculpture house in Liège (1967-1968) was designed in a similar, experimental way by the Belgian architect Jacques Gillet, in collaboration with the sculptor Félix Roulin and the engineer René Greisch. However, in the scenery of $20^{\text {th }}$ century Belgian architecture, it stands alone as an exception.

\section{In search for a new architecture}

\subsection{Kindred spirits}

Born in Liège in 1931, Jacques Gillet graduated from the Department of Architecture of the 'Académie des Beaux Arts' in Liège in 1956 [2]. One of his teachers was the Belgian architect Georges Dedoyard, an important exponent of the modern movement in Liège [3]. Gillet returned to the Académie as professor in 1964, which was later on renamed 'Institut Supérieur d'Architecture Lambert Lombard'. He conducted research on spontaneous architecture and the integration with nature [4]. He was also very interested in new building techniques and construction methods, which gave a certain creative liberty to the design process. Always being very eager to collaborate with artists and engineers, he looked upon architecture as a synthesis of art and science, a true unity between form and material.

In 1962, the Belgian engineer Jean-Mary Huberty (1932) asked Gillet to act as aesthetic advisor on the facades of his private house in La Hulpe, near Brussels. As a result, Gillet came in contact with two experts on concrete technology and was introduced to the possibilities of concrete [5]. The house was designed by Huberty himself in collaboration with André Paduart (1914-1985), both civil engineers, the former conducting research on concrete technology for the Belgian Federation of the Cement Industry, the latter being particularly specialised in the technology of thin concrete shells. The house stands out as a revolutionary and intellectual tour de force, in which these two young masters in concrete technology exploited the characteristics of the material to the utmost limit. Two parabolic hyperboloids, or hypars, were combined, thus defining the overall layout of the plan. The hypars were constructed as a concrete shell on a framework of wooden boards and thermal insulation. The shell of the concrete vault is only 5 centimeters thick. The collaboration led to a design in which both architectural and technological qualities stand out, but also demonstrates that it was not simple to go off the beaten track [5].

During the early sixties, Gillet came into contact with kindred spirits. In 1962 he became acquainted with the sculptor Félix Roulin $\left({ }^{\circ} 1931\right)$ and the painter Gabriël Belgeonne ( $\left.{ }^{\circ} 1935\right)$, when their project for an auditorium for chamber music was granted the first prize in a competition on 'The synthesis of plastic 
arts', organized by the Belgian Ministry of Cultural Affairs in $1961[6,7]$. During the same year, Gillet met the Liège engineer René Greisch (1929-2000). Greisch was notable for his spirit of research and innovation. Greisch always tried to improve available techniques or simplify their implementation, qualities that were highly valued and shared by Gillet [8]. Gillet and Greisch were soon commissioned by the Liège University to design the Laboratory of Radiobiological Research. The building was completed in 1964 [9]. Later the same year, together with Félix Roulin, they were commissioned with the design of an observatory station for the Astrophysical Department of the Liège University $[4,10]$. The design was undertaken in the same architectural language, which was later applied in the sculpture house in Liège. Although the observatory station was never realized, its design marks a first important phase in the collaboration of these three artists towards a synthesis of arts; a congenial group was formed.

In 1966, Gillet and Roulin collaborated with Belgeonne in the design of his private house and studio. The design, based on the same organic, architectural language, was constructed in wood and metal, as opposed to the auditorium for chamber music and the observatory station, which were designed to be constructed in concrete [10]. Around that time, several projects were undertaken, mostly by the twosome Gillet/Roulin, such as the private house and studio for a painter and a private house for a doctor [4]. Eventually, in 1967, Gillet's brother was willing to participate fully in the realization of the architect's dream and asked the team to design a private house for his family of six in the surroundings of Liège.

\section{2 'Living-sculpture'}

The experimental attitude of the physical-chemistry research scientist owner served as the basis for the entire approach to the project: "What is a house, for us as individuals, for our family, for this very place and this point in time?" was the first question [11]. After expressing his deepest concerns, the owner gave the team the chance to not only put their ideas into effect, but to do this at their own pace. For almost three years, Gillet, Greisch and Roulin sought, studied, tested, discussed and eventually built this 'living-sculpture', made to measure [4, 9].

Inspired by nature and organic forms, the design was undertaken as a synthesis of arts. According to their own words, they didn't want to start a revolution, but simply wanted to create something new, opposed to the standardisation of forms in architecture and the conditions of mankind's accommodation of those times, out of touch with nature [9]. It is not coincidental that all the comparisons the realization of this sculpture house have brought about, call forth associations with nature: a cave dwelling, a big mushroom in the middle of a forest or even a tortoise protected by his carapace [12]. The architectural language can best be described using the architect's own words: "We constantly tried to render these curves responsive and firm, which otherwise would flag and sag, becoming flabby and without vigour. But we did not want to geometrize these lines or standardize them. Spontaneity, tightness inspired by nature: purity, true simplicity — which is not of form but of soul-freshness that 
so many are longing for and that cannot be commercialized without dying forthwith. To let others taste and share the plenitude of a curve, the boldness of a shape, the élan, the right place of a stroke or a volume, the play of light, is the most important role of this 'thing', 'open to friends, ideas, emotion' according to the inhabitants' saying." [11].

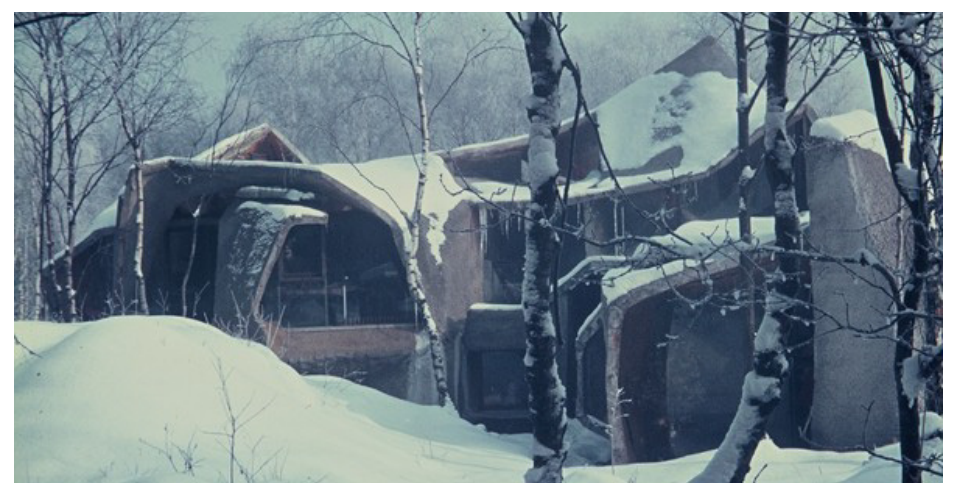

Figure 1: $\quad$ Sculpture house after completion in 1968 [13].

Describing the project outlines is far from simple. The ground plan is composed of four discrete wings: the living room facing south; the study, cloakroom, master bedroom and bathroom facing east; the dining room and kitchen facing west; and finally the children's bedrooms and bathroom towards the north, sunlit by windows facing both east and west. A distinction is also made in elevation: the garage is located at the lowest level of the site; the floor level of the common rooms is situated half a floor level higher, thereby fully exploiting the natural differences in the height of the terrain. The floor level of the parents' private wing is situated between the floor levels of the common rooms and the children's private wing; the latter being raised again half a floor level according to the common rooms. The children's bedrooms are superimposed on the garage. By creating a split-level, the architect obtained the two meters of height necessary for the garage without elevating the whole building.

These outlines are to be seen as a blueprint or diagram, put on paper so the team did not set to work without a set plan. The architect made a schematic drawing of his intentions, passed it on to the sculptor, who placed his own interpretation upon it, and the whole process started all over again. The facts and figures of the plan were touched upon, but not at all fixed. The design process was far from analytical or rational and the house was certainly not intended to be described that way. To understand the true meaning of the sculpture house, one has to visit the house and investigate the intentions of the designers. "Why this sculpture house? Explaining it would appear to be justifying it or making the design become 'logical'. Explaining it means that one has to assume the 'rational' to understand. Here, there is nothing to understand. Here, you can feel everything, subjectively." [4]. 
The inhabitants, answering many questions about how they could possibly live within those forms, simply replied with "And you, in yours?" [14]. Although many people had to be persuaded or convinced of the qualities of this new architecture, there were no great difficulties in obtaining the necessary permits. The local Department of Urban Planning and the municipal authorities truly believed in the possibilities of this project and displayed a certain audacity in authorizing this experiment $[9,15]$.

When construction was finished, the project began to lead a life on its own. Acquiring autonomy and independency towards the designers, the house immediately took on a dialogue not only with the visitors but especially the inhabitants. The moment they entered their new house, they really felt at home and became one with the project [12].

Creating such harmony and intimate peace was most important to the sculptor Roulin: he saw the sculpture house as a sculpture where the 'inner void', in contrast to the mass, was to be inhabited. He describes his own metier as manipulating and handling the forms and sensibility of raw materials, while architecture deals with the material of space, which is not at all less expressive but different, dealing with the area which has to be inhabited. Crossing the threshold between these two professions, led to a sculpture in which one penetrates, constantly revealing an entity of volumes and forms in perpetual movement to the inhabitant [14].

\section{Work in progress}

The project is not to be seen as a reaction against the building industry in general, since the team explored and experimented with new building techniques and materials throughout the entire design. It is a reply to the development of standardized forms and products, and at the same time a passionate plea in favour of an industrial policy which gets to the core of the matter: the molecule, the atom, the electron. "I believe in the miraculous industry of the tool made to measure the hand, material made to measure the human body, space made to measure the heart, Architecture made to measure the Inhabitant. I believe in the possibilities of this industry to provide for close contacts and let us delight in something: the delight in taking a venture, the pleasure of participating and the joy of constructing together. Never again the industry of the imposed or readymade." [4]. Partaking in this process was at least as important to the team as the achieved results. The mode of operation, the way in which the design was attended to, became a purpose on its own. Refusing to be driven back on traditional means, the team resorted to an uncommon construction method of projecting concrete onto a metal grid, which served as a projecting form itself.

\subsection{Marking the outlines}

During the design process, very few detail drawings were made. The scale models, first in modelling clay and later in an aluminium wire mesh, were the most important instruments by which to translate ideas [10]. When construction 
started in April 1967, the overall structure was outlined, based on the aluminium wire mesh scale model, in reference to a few fixed elements. As these fixed elements, namely the concrete floor levels and chimney, are best served by horizontal and vertical planes, it was unnecessary to construct them in a nontraditional, sculptural way [16]. Crenellated steel bars, extending the floor levels and chimney, served as reinforcements. Measuring 8 millimeters in diameter, these bars were interspaced at 20 centimeters in two directions, thus creating a two-dimensional grid [2].

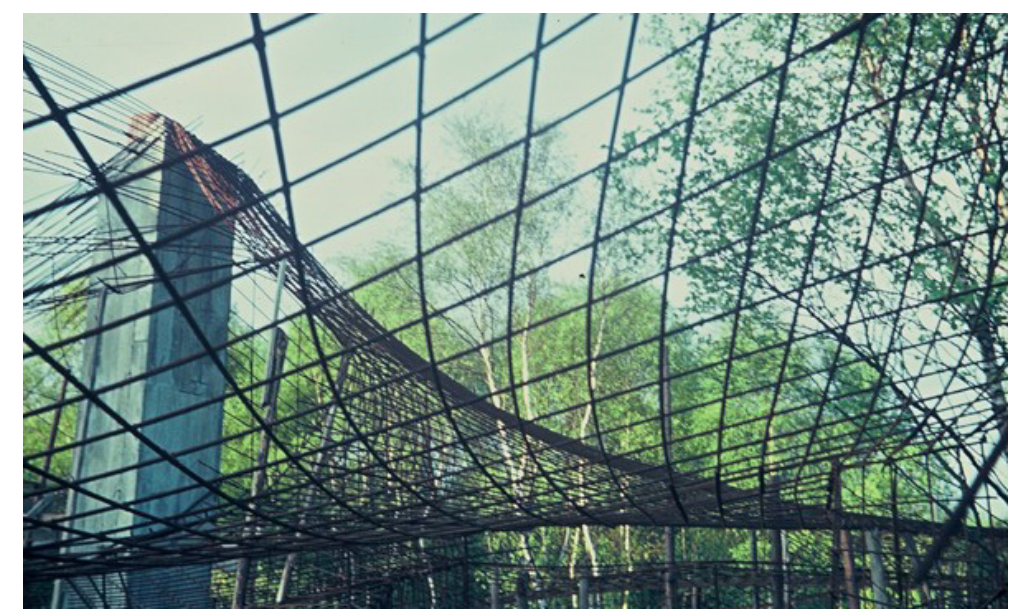

Figure 2: $\quad$ Steel lattice attached to the chimney.

Temporarily supported with thin wooden trunks, the lattice work was given shape by combining three distinct basic forms: the arch, catenary curve and parabolic hyperboloid. Given that the course of the lattice was not meticulously defined in advance, the shape was determined by experiment, by touch. Design and construction were dealt with together, according to four parameters: the inner space and the incidence of light, the future down course of the water, the stability and the sculptural characteristics. Therefore the architect, sculptor, engineer and client were constantly finalizing the generic form, very accurately, without there being a strict division of tasks. It appeared that the engineer, paradoxically, was most concerned with the sought-after sculptural or spatial effects [17].

Regarding stability, only a small part of the construction was meticulously calculated by the engineer. Full size rupture tests were conducted by the building contractor before starting construction, to determine possible difficulties and to define the most economical shapes and curves. With the result of these tests in mind, the actual construction was based on experience, intuition and experiments with life loads. When the ultimate form was outlined, the strength of the construction was once more tested on the spot by exerting concentrated pressure. Temporary supports were removed; workman and visitors of the construction site climbed the roof, moving up and down with a certain cadence. Wherever the 
deformation exceeded 25 centimeters, the engineer reinforced the construction. This eurhythmics was right up the alley of the numerous students working on placement at the site, under the expert guidance of the architect [2].

The window frames, U-shaped profiles, were bent and cut at the spot by the team. Much attention was paid to the rigidity of their form and their exact verticality, so they would contrast to the sculptural concrete mass. Neither the steel profiles nor any other part of the structure were preventively treated or galvanized. The window profiles did however receive a thin coat of a transparent, dark paint. Economical use was made of the available materials, which were chosen for their easy implementation, organic qualities or even their availability and beneficial prices [2].

\subsection{Gunniting}

Once the construction was sufficiently sturdy and solid, the next step was undertaken. An expanded iron mesh was fixed onto the steel bars, serving as projecting form. The casco was given its mass by the process of gunniting a fastsetting concrete onto it: direct, immediate and efficient. A very dry and compact concrete was gunnited on the mesh, setting in less than 15 minutes. This technique, mainly used for constructing blast-furnaces and grottos, was at this time very uncommon in Belgium. As it had never before then been used to construct a private home, a specialised team was asked to implement it.

The Czech-Belgian firm Pasek, established in 1960, was one of the only firms experimenting with sandblasting and the projecting of dry mortar. They had even designed their own projecting machine, Refra-Gun [18]. The team working on the Liège construction site consisted of 4 men, working in pairs. The first team handled the spraying hose, attached at the rear end to a large barrel, which contained the dry concrete. The barrel was divided into two compartments, so that the barrel could be continually refilled by one team, while the other team was gunniting. Water was not added until the very last moment, at the spray-gun nozzle, which resulted in a very dry concrete. The final surface was, when properly applied, very compact and impermeable to water [2].

As gunniting is not a tidy construction technique, precautions had to be taken. The window profiles were covered and small, temporary strips were placed at the edges of the shell structure to create a clear boundary between the house and its surroundings. Almost 15 percent of the concrete is lost during the process, as it shoots away from the mesh. This did not go to waste, as the architect used this to pave the access road to the house [2].

Concrete was sprayed at an angle of $45^{\circ}$. If concrete had been sprayed perpendicularly to the surface, considerably more than 15 percent of the concrete would be lost. Another advantage of this 'inclined technique', personally developed by Stephan Pasek [9], is that any water trying to penetrate the concrete shell, is drained immediately due to the inclined layers of concrete. Workmen were thus also enabled to estimate the thickness of the concrete shell. They had to carefully notice very small details, such as changes in the consistency of the concrete, and take immediate action to ensure a consistent product. The 
responsibility shouldered by these workmen while participating in this experimental and revolutionary project, should not be underestimated [9].

The overall thickness was set at 5 centimeters and was only increased where implied by the construction. At some places, such as corbellings and clear-cut edges, supplementary stiffening and strengthening were necessary at a distance of 50 centimeters parallel to the edge. Girders were formed at the edge by aligning 4 steel bars, all measuring no more than 8 millimeters in diameter. To ensure a strong and rigid connection between girder and lattice, additional steel braces, measuring 5 millimeters in diameter, were folded by students into a triangular shape, wrapped around the girder and welded to the lattice. The cross section of the girders measures 7 centimeters, so the entire thickness of the construction locally amounted to around 12 centimeters [2].

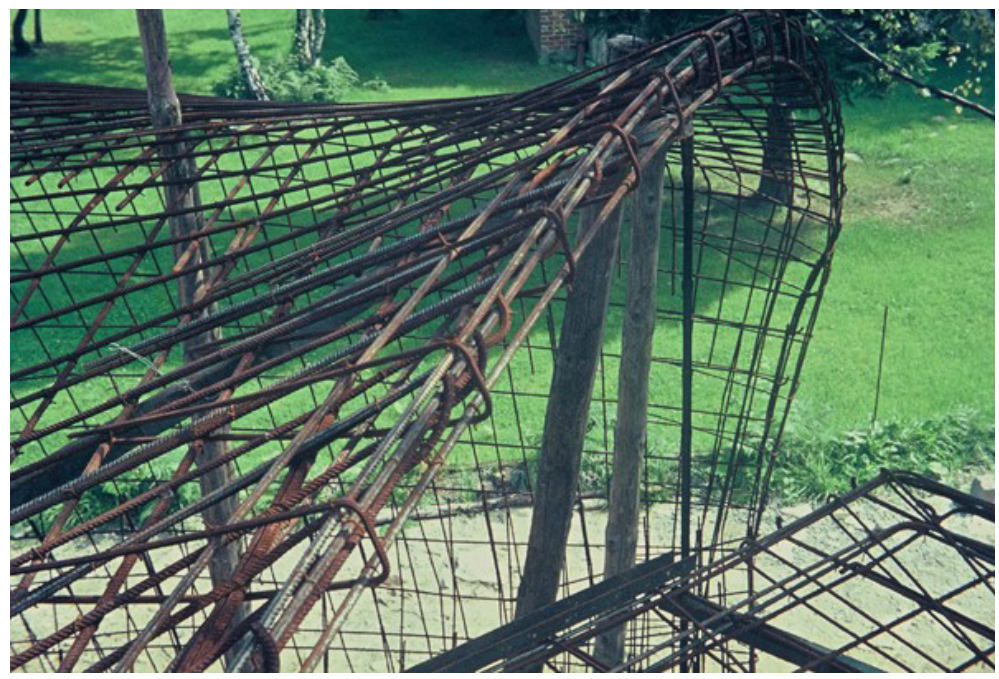

Figure 3: $\quad$ Steel 'girders' at the edge.

\subsection{Completion of the building process}

Thermal insulation was provided by a rigid polyurethane foam projected with a spray-gun from the inside. Over the years, it has matured in the natural light and acquired a warm and nuanced colour [11]. Since this insulation was not universally applied, an additional, very thin layer of sprayed concrete was sometimes necessary to cover the iron mesh on the interior.

Beside this thermal insulation, no corrective measures or provisions were taken. The concrete was deemed waterproof and the roof thereby did not receive an extra coat. Construction was finished in September 1968, a total building time of 14 months (construction was interrupted during winter) [2]. When asked to compare to traditional building methods regarding construction time and building costs, the architect replied that he did not intend to be competitive. He was however quite certain that the building costs would not exceed those of a traditional house for a family of six [19]. 
Despite the fact that the house was in no need of supplementary measures during the following decades, some renovation became inevitable during the late eighties. The impermeability to water had been affected and needed to be repaired. The exterior was restored by impregnating it with a highly fluid, waterrepellent, silicate based resin. Additionally, a special coating of semi-rigid epoxy resin was applied to those surfaces which had suffered the most from the down course of the water $[2,9]$.

\section{Continues}

While designing this sculpture house in Liège, the team was granted a second commission for a similar house to be erected on a hill close to a former World War I fortification. It was designed by the same team, but as the terrain and the personality of the clients was different, the ultimate form was also different. At the very last moment however, right before going on to the construction phase, the clients decided that this new architecture was too revolutionary after all $[9,20]$.

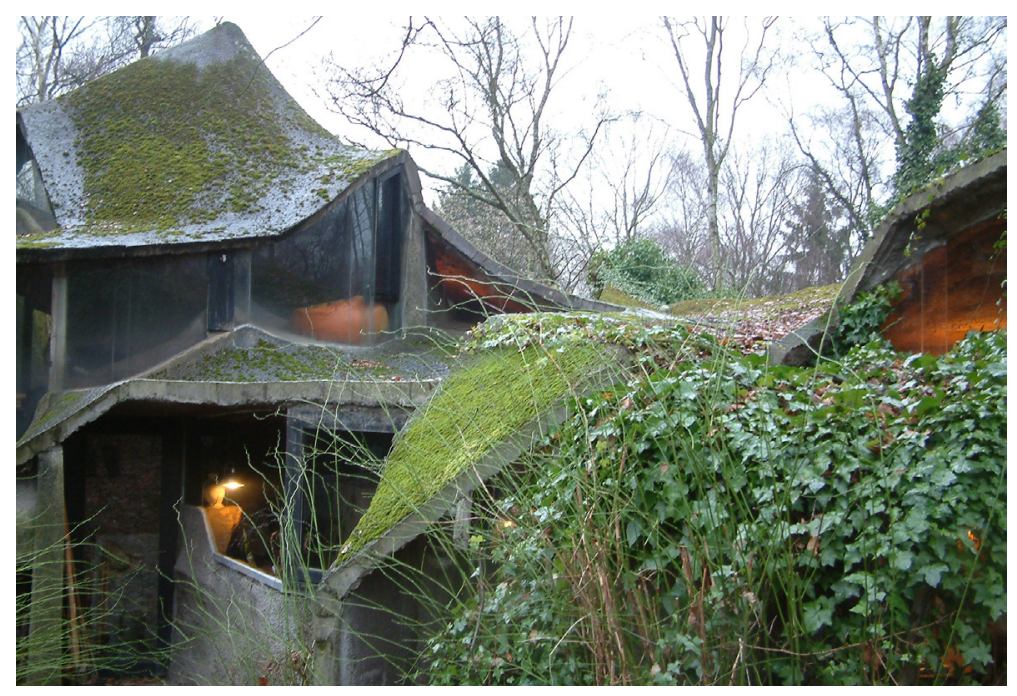

Figure 4: $\quad$ The sculpture-house, 2006.

It wasn't until the late seventies that another example of sculpture architecture appeared in Belgium. The architect Philippe Mousset, who had paid numerous visits to the building yard in Liège, erected a sculpture house in Fleurus [9]. The same uncommon genesis and architectural language was utilized, the applied technique was however a bit different: a glass fibre reinforced plaster was sprayed on an elastic tissue in stead of an iron mesh [21].

During the following years, a few architects followed in Gillet's footsteps, as he began to hold a course on organic architecture at the Institut Supérieur 
d'Architecture Lambert Lombard in 1978. Henry Chaumont, Bernard Herbecq, Eric Furnémont, Yves Delhez and Vitor Forte are, among others, some of Gillet's former students still engaged on organic architecture [9].

The work of Jacques Gillet, first and foremost the sculpture house in Liège, still finds itself the subject of great public interest. This active interest is demonstrated by recent articles on the sculpture house published in international magazines, such as the German Deutsche Bauzeitung, the Swiss TEC 21 and the Austrian GAM, and also exhibitions where the sculptor house occupies a prominent place [22-25].

Recent examples of modern architecture, such as the Educatorium by Koolhaas (OMA) and the Minnaertbuilding by Neutelings Riedijk Architects, both in Utrecht, demonstrate that this construction technique of projected concrete is still topical, bringing forth intellectual and architectural fireworks.

\section{References}

[1] Ragon, M., Où vivrons-nous demain?, Paris, Laffont, 213 p., 1963.

[2] Gillet, J., Personal communication, 4 January 2006, architect and professor on organic architecture, Institut Supérieur d'Architecture Lambert Lombard, Liège, Belgium (retired).

[3] Van Loo, A., Repertorium van de architectuur in België, Antwerpen, Mercatorfonds, pp. 240-241, 2003.

[4] Bekaert, G., Bouwen in België 1945-1970, Brussel, Nationale confederatie van het bouwbedrijf, pp. 317-318, 1971.

[5] Huberty, J.-M., Personal communication, 12 January 2006, civil engineer and architect (retired).

[6] Belgeonne, G., Personal communication, 21 December 2005, painter, engraver, former head of 'L'Ecole Supérieure des Arts Plastiques et Visuel de l'Etat', Mons, Belgium and 'L'Ecole Nationale Supérieure des Arts Visuel - La Cambre', Brussels, Belgium.

[7] Joly, P., Architectures de Sculpteurs, L'Architecture d'aujourd'hui, 115, pp. 85, 1964.

[8] Greisch, R., Bureau d'études Greisch, Antwerpen, de Singel, 207 p., 1996.

[9] Gillet, J., Personal communication, 17 January 2006.

[10] Roulin, F., Personal communication, 17 January 2006, sculptor.

[11] Gillet, J., The Sculpture House, (unedited paper), 1978.

[12] Gillet, J., Habitat selon la nature, Neuf, 18, pp. 12-15, 1969.

[13] Pictures 1,2 and 3 were taken by Gillet, J. Picture 4 was taken by the author.

[14] Gillet, J. \& Roulin, F., Habitation-sculpture près de Liège, Environnement, 3, pp. 115-120, 1971.

[15] X, La maison sur mesure, Moustique, 5 November 1967.

[16] Henrion, P., La maison-sculpture d'Angleur, Art \& Fact, 12, pp. 185-190, 1993.

[17] Roulin, F., Personal communication, 15 December 2005. 
Design and Nature III: Comparing Design in Nature with Science and Engineering 59

[18] Stouffs, S., Spuitbeton, een techniek met toekomst, (unedited essay), pp. 13-14, 1985.

[19] A.S., Une maison-grotte à Angleur, La Libre Belgique, 16 April 1968.

[20] X, Habitacle pour une famille sur un promontoire bien dégagé, $\mathrm{La}$ Maison, 2, pp. 59-60, 1967.

[21] Mousset, P., Personal communication, 17 January 2006, architect.

[22] Holl C. \& Merx, L., in die Jahre gekomen. Einfamilienhaus in Lüttich 1967-1968, Deutsche Bauzeitung, 10, pp. 74-80, 2004.

[23] Holl, C. \& Merx, L., Naturnähe und Naturdistanz, Graz Architecture Magazine, 2, pp. 42-61, 2005.

[24] Holl, C. \& Merx, L., Die Höhle als Bild und Vorstellung, Tec 21, 18, pp. 10-15, 2005.

[25] Exposition on 'Architecture organique', Musée d'art moderne et d'art contemporain, Liège, 23 December 2005 - 5 February 2006. 